\title{
THE IMPACT OF COVID-19 ON CONSUMER BEHAVIOR IN THE RETAILING INDUSTRY OF LEBANON
}

\author{
Bassam Tarhini ${ }^{1 *}$, Layal Hafiz ${ }^{2}$ \\ ${ }^{I}$ The Bucharest University of Economic Studies - ASE Bucuresti, Romania, bassam.tarhini@liu.edu.lb \\ ${ }^{2}$ Lebanese International University - LIU, Lebanon
}

\begin{abstract}
COVID-19 has changed many aspects of human lives. Life was paused for a while and humanity has been exposed to many threats unprepared at most levels. Several studies were conducted to understand human behavior amid crises and their behavior during COVID-19. Panic and spiritual buying dominates the buying behavior.

This research investigates the emerged trends to the retail industry amid COVID-19. Several hypotheses were tested to understand the cause and effect relationship between the brick-and-mortar and online shopping. In order to reach a realistic result a quantitative research was conducted and a non-probability convenience sampling method was used where 191 respondents answered the survey questions on a 5 point Likert and nominal scales.

It was found that consumer behavior is common across different countries amid COVID-19 with slight variation related to online shopping due to lack of trust with online sources. It was noticed that Lebanese post the pandemic became less price sensitive towards health products as they seek quality and willing to pay more to get it.
\end{abstract}

Keywords:

COVID-19, retailing industry, consumer behavior, online shopping

DOI: $10.24818 / \mathrm{CTS} / 3 / 2021 / 1.03$

\section{Introduction}

The lockdowns as a result of COVID-19 spread in Lebanon as in many other countries have changed how businesses operate and how people carry on with their daily activities. Such behavior change has had many implications on businesses and mainly the physical stores that were subject to closure during the lockdown period. Adding to this issue the economic crises that the country was facing prior to the corona pandemic which started to appear in 2019 that has worsened the economic situation. And since people's main concern is their health, their purchase behavior has shifted to the purchase of essential products and services. This has worsened the economic situation in Lebanon, however, the question remains if this pandemic will have long term implications on the economy and consumer behavior or whether things will go back gradually to normal once the virus is contained.

\section{Literature review}

\subsection{Consumer Behavior}

It is customers' decision intention followed by the physical action of assessing, possessing, use, and consumption of products in order to fulfill ones' needs and wants (Solomon et al., 2012). Consumer behavior helps us understand why a customer made a specific brand choice at a certain location and time (Rai, 2020). It provides insights to marketers on why customers make certain purchase decisions and form attitudes and habits towards a certain brand (Babu and Kumar, 2020).

It is explained as customers' inner thinking and outer visible reaction towards goods and services consumer behavior requires thorough understanding of human psychological, sociocultural, and physical actions of selecting, purchasing, use, and consumption of goods and services (Peter et al., 1999)

\subsection{COVID-19 and World Economy}

What made COVID-19 more dangerous from previous influenzas is that the world economy today has become as one small village with higher globalization (Civrik, 2020). In order to stop the spread of corona virus, countries had to undergo a complete lockdown, where people movement in terms of

\footnotetext{
* Contact author
} 
traveling and transport has stopped, thus affecting the global economy, mainly the tourism and transport industry (Babu and Kumar, 2020). Not to mention the direct effect on GDP of every country due to the high cost burden of treating and rehabilitating COVID-19 patients causing a severe economic crisis in countries like India and others (Revathy \& Balaji, 2020).

\subsection{Retailing Industry}

Retailing is the activity of making goods and services available directly for final consumer (Kotler et al., 2016). The development of new business models that raised due to the changes in the competitive environment necessitated diversification in the retail structure (Reynolds et al., 2007). In poorer markets, retailing is mainly still served by old-fashioned traditional-single unit family business retailing structures serving lower income consumers (Aithal, 2012; D'Andrea et al., 2006), unlike richer markets that are predominantly served by multi-unit larger stores (Feeny et al., 1996).

Modern retailing adopts latest technologies in collecting data, merchandising, inventory, and branding strategies and are characterized by multiple line forms, wider collection (Myers and Alexander, 1997), advanced looking facilities (Trappey and Lai, 1996), and safe and clean atmosphere.

\subsection{Retailing Industry amid COVID-19}

COVID-19 had some impacts on the consumer as a result of social distancing, prohibiting customers from dinning out to more staying home and focus more on grocery shopping. In such sense, retailers should have a bigger supply from wholesalers to fulfill consumers increased demand for goods (Lusk, 2020). Social distancing also created hesitations among customers to visit crowded shopping areas and instead preferred to visit the nearby grocery shops in order to buy fresh groceries that cannot be purchased online due to the freshness concern regardless of the risk of getting infected (Lahiri and Sinha, 2021).

Retailers should not expect that their business will go back to its original format since the COVID-19 caused additional pressure besides the e-commerce concerns, to force retailers to shift their focus from brick-and-mortar to online full presence. In other words, they need to shift from just having a browsing web options to more like searching, purchasing, and returning options online. Customers post the corona pandemic will only expect that retailers have integrated services that allow customers to shop online and chose how to pick up their products (Denise, 2020).

Consumer behavior that was adopted during the quarantine with more online shopping and less physical stores visit will expect to continue. In such sense, retailers need to switch gears and become proactive instead of just waiting in order to prosper (Denise, 2020).

\subsection{Consumer Behavior amid COVID-19}

Just like consumer behavior changed after previous contagious viruses, it will for sure after the COVID19. What is important is to study this behavior and prepare for future pandemics (Dali et al., 2020). The uncertainty that consumers are experiencing as a result to COVID-19 pandemic along with government restrictions from social distancing, quarantine, to travel restrictions have created the concept of panic buying through storing daily use products (Knoll, 2020). Such change in consumer behavior has caused changes to the channels of distributions operations in the United States (Leone et al., 2020).

People's daily life has changed due to the corona virus in areas related to work, shopping, and communication with others. People are focusing more on necessities in their shopping (Chauhan and Shah, 2020). It was also noticed that people are shifting towards basics in life with an increase sense of social responsiblity towards the society and the environment by fousing their consumption on products that are eco-friendly (Aleksic et al., 2021).

\section{Methodology}

The research philosophy adopted is critical realism where the reality cannot be free from human perception and construction. What is observed and interpreted is a result of our own perspective and background (University of Warwick., n.d.). Data collection for the quantitative search is done using an 
online survey distributed on a non-probability snowball sampling of 191 respondents using 5 -scale Likert questions and nominal questions.

A cross sectional research design was used since consumer behavior was studied one time during the COVID-19 pandemic.

The information that was collected via the survey and was analyzed using SPSS. Fischer's test was mainly used.

\section{Results}

\subsection{Analysis for the quantitative research (survey)}

The aim of this research is to understand about the impact of Covid-19 pandemic on consumer buying behavior towards the retail industry in Lebanon and the change in consumer behavior toward retail industry in Lebanon.

Table no. 1: Age, Gender, and Monthly Income of Respondents

\begin{tabular}{|ccc|ccc|}
\hline 1. Age & Frequency & Percent & 3.Monthly average income & Frequency & Percent \\
$18-24$ & 108 & $56.5 \%$ & $0-2,999,999$ L.L & 110 & $57.6 \%$ \\
$25-34$ & 44 & $23.0 \%$ & $3,000,000-5,999,999$ L.L & 38 & $19.9 \%$ \\
$35-44$ & 16 & $8.4 \%$ & $6,000,000-8,999,999$ L.L & 22 & $11.5 \%$ \\
$45-55$ & 10 & $5.2 \%$ & $9,000,000-11,999,999$ L.L & 10 & $5.2 \%$ \\
$>=55$ & 13 & $6.8 \%$ & $12,000,000-14,999,999$ L.L & 6 & $3.1 \%$ \\
Total & $\mathbf{1 9 1}$ & $\mathbf{1 0 0 . 0 \%}$ & $15,000,000-17,999,999$ L.L & 5 & $2.6 \%$ \\
\cline { 1 - 2 } 2.Gender & Frequency & Percent & Total & $\mathbf{1 9 1}$ & $\mathbf{1 0 0 . 0 \%}$ \\
Male & 79 & $41.4 \%$ & & & \\
Female & 112 & $58.6 \%$ & $\mathbf{1 0 0 . 0 \%}$ & &
\end{tabular}

Source: Tarhini and Hafiz, 2021

The greatest percentage of participants belongs to the age group 18-24. Around 57\% of the surveyed individuals belong to this age group. Around 70\% are youth belonging to the age group 18-34.

The majority of respondents are females. As $58.6 \%$ of the surveyed persons were females.

The biggest weight is given to income range between 0 and 2,999,999 L.L. 57.6\% reported they receive between 0-2,999,999 L.L. This may be related to the fact that the majority belong to the age group 1824 meaning that they are still students or recently employed or to the fact that the economic situation is down.

Table no. 2: Price Sensitivity for Necessity Products

\begin{tabular}{|l|c|c|}
\hline $\begin{array}{l}\text { "If the price of a health, medication, or sterilization product (necessary for your health) goes up, I } \\
\text { would still buy the product." }\end{array}$ & Frequency & Percent \\
\hline & 6 & $3.1 \%$ \\
\hline Strongly disagree & 22 & $11.5 \%$ \\
\hline Disagree & 39 & $20.4 \%$ \\
\hline Neutral & 98 & $51.3 \%$ \\
\hline Agree & 26 & $13.6 \%$ \\
\hline Strongly agree & $\mathbf{1 9 1}$ & $\mathbf{1 0 0 . 0 \%}$ \\
\hline Total & &
\end{tabular}

Source: Tarhini and Hafiz, 2021

$64.9 \%$ claim that they would buy a health medication or sterilization product even if its price goes up. This is because they compute value against expenses. Amid Covid-19, consumers are very concerned about their health. 
Table no. 3: Price Sensitivity for Restaurants

\begin{tabular}{|l|c|c|}
\hline $\begin{array}{l}\text { "If a restaurant takes the necessary precautions against Covid-19, I would choose to go there even if it } \\
\text { costs higher." }\end{array}$ & Frequency & Percent \\
\hline Strongly disagree & 29 & $15.2 \%$ \\
\hline Disagree & 42 & $22.0 \%$ \\
\hline Neutral & 40 & $20.9 \%$ \\
\hline Agree & 67 & $35.1 \%$ \\
\hline Strongly agree & 13 & $6.8 \%$ \\
\hline Total & $\mathbf{1 9 1}$ & $\mathbf{1 0 0 . 0 \%}$ \\
\hline
\end{tabular}

Source: Tarhini and Hafiz, 2021

$41.9 \%$ agree that they would pay more for a restaurant that offers health measures against Covid-19. That is not a majority. This can be explained by the fact that income of $57.6 \%$ is between $0-2,999,999$ L.L. So, they are price sensitive for restaurants services.

Table no. 4: Purchase through Delivery Services

\begin{tabular}{|l|c|c|}
\hline $\begin{array}{l}\text { "Amid Covid-19, I prefer to buy through delivery services than go in person to buy groceries." } \\
\text { (grocery: food and other commodities) }\end{array}$ & Frequency & Percent \\
\hline Strongly disagree & 43 & $22.5 \%$ \\
\hline Neutral & 56 & $29.3 \%$ \\
\hline Agree & 63 & $33.0 \%$ \\
\hline Strongly agree & 29 & $15.2 \%$ \\
\hline Total & $\mathbf{1 9 1}$ & $\mathbf{1 0 0 . 0 \%}$ \\
\hline
\end{tabular}

Source: Tarhini and Hafiz, 2021

Less than 50\% (45.2\%) agree to buy through delivery services amid Covid-19. $29.3 \%$ are neutral.

Table no. 5: Online Shopping Amid Covid-19

\begin{tabular}{|c|c|c|}
\hline & Frequency & Percent \\
\hline Strongly disagree & 12 & $6.3 \%$ \\
\hline Disagree & 39 & $20.4 \%$ \\
\hline Neutral & 48 & $25.1 \%$ \\
\hline Agree & 70 & $36.6 \%$ \\
\hline Strongly agree & 22 & $11.5 \%$ \\
\hline Total & 191 & $100.0 \%$ \\
\hline
\end{tabular}

Source: Tarhini and Hafiz, 2021

Approximately 50\% (48.1) agree that they prefer to buy online if a safe convenient and trustworthy source was available. $25.1 \%$ were neutral. $26.7 \%$ disagreed.

Table no. 6: Type of Products Purchased amid Covid-19

\begin{tabular}{|l|c|c|}
\hline \multicolumn{2}{|c|}{ "Since the onset of Covid-19, I am shopping basic needs and spending a little or nothing on luxury." } \\
\hline Strongly disagree & Frequency & Percent \\
\hline Disagree & 5 & $2.6 \%$ \\
\hline Neutral & 25 & $13.1 \%$ \\
\hline Agree & 21 & $11.0 \%$ \\
\hline Strongly agree & 94 & $49.2 \%$ \\
\hline Total & 46 & $24.1 \%$ \\
\hline
\end{tabular}

Source: Tarhini and Hafiz, 2021

$73.3 \%$ agree that they are buying mostly the essential needs and spending little on luxury. Only $15.7 \%$ refuted the statement. 
Table no. 7: Reason for in-person shopping amid Covid-19 (1)

\begin{tabular}{|l|c|c|}
\hline $\begin{array}{l}\text { "Even it is not safe, I would still go to the store to buy my groceries because online sources are not } \\
\text { available." }\end{array}$ & Frequency & Percent \\
\hline & 5 & $2.6 \%$ \\
\hline Strongly disagree & 45 & $23.6 \%$ \\
\hline Disagree & 48 & $25.1 \%$ \\
\hline Neutral & 76 & $39.8 \%$ \\
\hline Agree & 17 & $8.9 \%$ \\
\hline Strongly agree & $\mathbf{1 9 1}$ & $\mathbf{1 0 0 . 0 \%}$ \\
\hline Total & &
\end{tabular}

Source: Tarhini and Hafiz, 2021

Table no. 8: Reasons for In-person buying amid Covid-19 (2)

\begin{tabular}{|l|c|c|}
\hline "Even if it is not safe, I would still go buy my groceries in person because I don't trust online sources." \\
\hline Strongly disagree & Frequency & Percent \\
\hline Disagree & 15 & $7.9 \%$ \\
\hline Neutral & 49 & $25.7 \%$ \\
\hline Agree & 59 & $30.9 \%$ \\
\hline Strongly agree & 54 & $28.3 \%$ \\
\hline Total & 14 & $7.3 \%$ \\
\hline
\end{tabular}

Source: Tarhini and Hafiz, 2021

Table no. 9: Reasons for In-person buying amid Covid-19 (3)

\begin{tabular}{|l|c|c|}
\hline $\begin{array}{l}\text { "Even if it is not safe, I would still go to the store to buy my groceries because delivery service is not } \\
\text { available." }\end{array}$ & Frequency & Percent \\
\hline & 10 & $5.2 \%$ \\
\hline Strongly disagree & 48 & $25.1 \%$ \\
\hline Disagree & 49 & $25.7 \%$ \\
\hline Neutral & 77 & $40.3 \%$ \\
\hline Agree & 7 & $3.7 \%$ \\
\hline Strongly agree & $\mathbf{1 9 1}$ & $\mathbf{1 0 0 . 0 \%}$ \\
\hline Total & &
\end{tabular}

Source: Tarhini and Hafiz, 2021

For $44 \%$ of respondents, they would still go in person to physical stores because delivery service is not available.

Table no. 10: Preference to Online Shopping after Covid-19

\begin{tabular}{|l|c|c|}
\hline & Frequency & Percent \\
\hline Strongly disagree & 25 & $13.1 \%$ \\
\hline Disagree & 84 & $44.0 \%$ \\
\hline Neutral & 54 & $28.3 \%$ \\
\hline Agree & 23 & $12.0 \%$ \\
\hline Strongly agree & 5 & $2.6 \%$ \\
\hline Total & $\mathbf{1 9 1}$ & $\mathbf{1 0 0 . 0 \%}$ \\
\hline
\end{tabular}

Source: Tarhini and Hafiz, 2021

An important finding is related to this statement. $57.1 \%$ of respondents disagreed with the idea of using e-commerce after the pandemic ends. Only $14.6 \%$ of respondents agreed. 
Table no. 11: Brand Loyalty for Basic Needs

\begin{tabular}{|l|c|c|}
\hline "I buy whatever brand is available of the groceries that are basic needs." \\
\hline Strongly disagree & Frequency & Percent \\
\hline Disagree & 6 & $3.1 \%$ \\
\hline Neutral & 40 & $20.9 \%$ \\
\hline Agree & 45 & $23.6 \%$ \\
\hline Strongly agree & 85 & $44.5 \%$ \\
\hline Total & 15 & $7.9 \%$ \\
\hline
\end{tabular}

Source: Tarhini and Hafiz, 2021

Table no. 12: Frequency of Visits to Physical Stores amid Covid-19

\begin{tabular}{|l|c|c|}
\hline How has Covid-19 impacted the frequency of your visits to physical stores? \\
\hline major decrease in frequency & Frequency & Percent \\
\hline minor decrease in frequency & 92 & $48.2 \%$ \\
\hline major increase in frequency & 64 & $33.5 \%$ \\
\hline no real impact to frequency & 10 & $5.2 \%$ \\
\hline Total & 25 & $13.1 \%$ \\
\hline
\end{tabular}

Source: Tarhini and Hafiz, 2021

$81.7 \%$ declared a decrease in frequency of visiting physical stores amid Covid-19. 5.2\% announced a major increase. $13.1 \%$ ensured no change in frequency.

Table no. 13: Go out or Stay at Home?

Choose the most suitable option for you.

\begin{tabular}{|l|c|c|}
\hline & Frequency & Percent \\
\hline Go out to any restaurant regardless of Covid-19 & 13 & $6.8 \%$ \\
\hline Go out to a restaurant that takes the necessary precautions against Covid-19 & 41 & $21.5 \%$ \\
\hline Stay at home and enjoy a take-out meal & 107 & $56.0 \%$ \\
\hline other & 30 & $15.7 \%$ \\
\hline Total & $\mathbf{1 9 1}$ & $\mathbf{1 0 0 . 0 \%}$ \\
\hline
\end{tabular}

Source: Tarhini and Hafiz, 2021

$56 \%$ prefer to stay at home and not go out to a restaurant although 21.5 are health conscious and would go to restaurants that take the necessary precautions against Covid-19

Table no. 14: Replacement of Products with Other Brands amid Covid-19

\begin{tabular}{|l|c|c|}
\hline $\begin{array}{l}\text { Over the past 12 months, have you replaced products you previously purchased regularly with other } \\
\text { brands available? }\end{array}$ & Frequency & Percent \\
\hline & 152 & $79.6 \%$ \\
\hline Yes & 27 & $14.1 \%$ \\
\hline No & 12 & $6.3 \%$ \\
\hline I don't know & $\mathbf{1 9 1}$ & $\mathbf{1 0 0 . 0 \%}$ \\
\hline Total &
\end{tabular}

Source: Tarhini and Hafiz, 2021

$79.6 \%$ have replaced products they regularly bought with other brands available. $14.1 \%$ said no. 
Table no. 15: Brand Loyalty amid Covid-19 (2)

\begin{tabular}{|l|c|c|}
\hline \multicolumn{2}{|l|}{ Which of the following statements is most accurate? } \\
\hline I switch brands less often today than ever before & Frequency & Percent \\
\hline I switch brands about the same amount as always & 29 & $15.2 \%$ \\
\hline I switch brands more often now than ever before & 46 & $24.1 \%$ \\
\hline Other & 112 & $58.6 \%$ \\
\hline Total & 4 & $2.1 \%$ \\
\hline
\end{tabular}

Source: Tarhini and Hafiz, 2021

Table no. 16: Physical Stores Visits after Vaccination

\begin{tabular}{|l|c|c|}
\hline \multicolumn{1}{|l|}{ Would a Covid-19 vaccine make you visit physical stores more often? } \\
\hline Yes & Frequency & Percent \\
\hline No & 105 & $55.0 \%$ \\
\hline I don't know & 51 & $26.7 \%$ \\
\hline Total & 35 & $18.3 \%$ \\
\hline
\end{tabular}

Source: Tarhini and Hafiz, 2021

$55 \%$ would go to physical stores more often after a Covid-19 vaccination. A considerable $26.7 \%$ said they won't.

Table no. 17: Will Life be the same before and after the Pandemic

\begin{tabular}{|l|c|c|}
\hline \multicolumn{1}{|l|}{ Do you think life after Covid-19 will be the same as life before Covid-19? } \\
\hline Yes & Frequency & Percent \\
\hline No & 32 & $16.8 \%$ \\
\hline Total & 159 & $83.2 \%$ \\
\hline
\end{tabular}

Source: Tarhini and Hafiz, 2021

$83.2 \%$ don't think that life will go back to normal after Covid-19. $16.8 \%$ disagree with them.

Table no. 18: Value System Amid Covid-19

\begin{tabular}{|l|c|c|}
\hline \multicolumn{3}{|l|}{ Has Covid-19 caused a change in your value system? } \\
\hline Yes & Frequency & Percent \\
\hline No & 134 & $70.2 \%$ \\
\hline Total & 57 & $29.8 \%$ \\
\hline
\end{tabular}

Source: Tarhini and Hafiz, 2021

To analyze the proposed trends descriptive statistics will be used.

$\mathrm{T}_{1}$ : The spread of Covid-19 has negatively affected the willingness of consumers to visit physical locations of stores.

Regarding the first trend that reflects the willingness of consumers to visit physical stores amid Covid$19,81.7 \%$ declared a decrease in frequency of visiting physical stores amid Covid-19.5.2\% announced a major increase. $13.1 \%$ ensured no change in frequency. This might be because the Lebanese are abiding to the lockdown measures forced by the authorities. It might be also related to the fear caused by the pandemic. It might be also due to the fact that during the pandemic, consumers focus on necessity needs and postpone the urge to satisfy other needs. However, 55.9\% would visit stores more often after being vaccinated.

T2: The spread of corona virus has negatively affected brand loyalty.

Three different questions in the survey were asked related to brand loyalty. It has been clear through the percentages that the spread has affected the brand loyalty. This might be to three reasons. The first is the fact that the Covid-19 situation has affected the economic situation as well and a number of consumers had to switch to less expensive brands. The second reason is the fact that many of the brands 
have disappeared from shelves due to lockdown. The third reason is the fact that for convenience purposes, consumers are buying whatever brand they find available at a store and not going to other stores to search for their favorite brand.

T3: The spread of Covid-19 virus has positively affected price sensitivity for essential products and negatively affected price sensitivity for luxury products.

As the data show, consumers are less price sensitive toward necessity products and mainly medical products as specified in the survey. $64 \%$ of consumers agree that they would buy a necessity product even if it costs higher. This is related to the fact that consumers have become very health conscious amid Covid-19. They have come to notice the importance of healthy, nutritious, and hygiene products such as sanitizers.

T4: The spread of Covid-19 has a positive effect on the preference to buy through delivery services and online shopping than physical shopping.

Unlike other countries, the pandemic hasn't created a trend of preference to buy through delivery services. The percentage shows that only $45 \%$ of the surveyed agree to buy through delivery services. This was further questioned through interviews and as it appears consumers in Lebanon have not gained trust in delivery services since they are not satisfied with the delivery services that never makes it on time and sometimes deliver the wrong item.

$48.1 \%$ of consumers agree that they would prefer to buy online through a safe channel. Not the majority agrees because many of the businesses haven't utilized websites or applications or online selling and because they don't trust digitized channels due to absence of regulations in Lebanon and the absence of good marketing. Opposed to results in other countries, the end of the pandemic means for $57 \%$ that they wouldn't go for online shopping.

T5: The spread of covid-19 has changed the priorities of consumers

Consumers have made some changes to their value systems. This is clear as $70 \%$ have agreed that the pandemic has caused a change in their value system. Upon rating the components of the value system, $62.3 \%$ gave the highest value to health and $65 \%$ gave the highest weight to family.

\subsection{Cross Tabulation Results}

H01: there is no statistically significant relationship between income and price sensitivity toward necessity products.

Table no. 19: Hypothesis 1

\begin{tabular}{|c|c|c|c|c|c|c|c|c|c|c|}
\hline \multicolumn{11}{|c|}{$\begin{array}{l}\mathrm{A}=\text { "If the price of a health, medication, or sterilization product (necessary for your health) goes up, I } \\
\text { would still buy the product." * What is your monthly average income? Crosstabulation }\end{array}$} \\
\hline & & & \multicolumn{6}{|c|}{ What is your monthly average income? } & \multirow[b]{2}{*}{ Total } & \multirow[b]{2}{*}{ Sig. } \\
\hline & & & $\begin{array}{c}0- \\
2,999,999 \mathrm{~L} \\
\mathrm{~L} \\
\end{array}$ & $\begin{array}{c}3,000,00- \\
5,999,999 \mathrm{~L} \\
\mathrm{~L}\end{array}$ & \begin{tabular}{|c|}
$6,6000,000-$ \\
$8,999,999 \mathrm{~L}$. \\
$\mathrm{L}$ \\
\end{tabular} & \begin{tabular}{|c|}
$9,000,000-$ \\
$11,999,999 \mathrm{~L}$. \\
$\mathrm{L}$ \\
\end{tabular} & $\begin{array}{c}12,000,000- \\
14,999,999 \mathrm{~L} . \\
\mathrm{L} \\
\end{array}$ & $\begin{array}{c}15,000,000- \\
17,999,999 \\
\text { L.L }\end{array}$ & & \\
\hline \multirow{2}{*}{\multicolumn{2}{|c|}{\begin{tabular}{|l|}
$\begin{array}{l}\text { Strongly } \\
\text { disagree }\end{array}$ \\
\end{tabular}}} & Count & 5 & 0 & 0 & 1 & 0 & 0 & 6 & \multirow{11}{*}{0.161} \\
\hline & & percent & $4.5 \%$ & $0.0 \%$ & $0.0 \%$ & $10.0 \%$ & $0.0 \%$ & $0.0 \%$ & $3.1 \%$ & \\
\hline \multirow{2}{*}{\multicolumn{2}{|c|}{ Disagree }} & Count & 13 & 3 & 3 & 1 & 1 & 1 & 22 & \\
\hline & & percent & $11.8 \%$ & $7.9 \%$ & $13.6 \%$ & $10.0 \%$ & $16.7 \%$ & $20.0 \%$ & $11.5 \%$ & \\
\hline \multirow{6}{*}{ A } & \multirow{2}{*}{ Neutral } & Count & 28 & 8 & 1 & 0 & 2 & 0 & 39 & \\
\hline & & percent & $25.5 \%$ & $21.1 \%$ & $4.5 \%$ & $0.0 \%$ & $33.3 \%$ & $0.0 \%$ & $20.4 \%$ & \\
\hline & \multirow{2}{*}{ Agree } & Count & 52 & 21 & 15 & 6 & 3 & 1 & 98 & \\
\hline & & percent & $47.3 \%$ & $55.3 \%$ & $68.2 \%$ & $60.0 \%$ & $50.0 \%$ & $20.0 \%$ & $51.3 \%$ & \\
\hline & \multirow{2}{*}{$\begin{array}{l}\text { Strongly } \\
\text { agree }\end{array}$} & Count & 12 & 6 & 3 & 2 & 0 & 3 & 26 & \\
\hline & & percent & $10.9 \%$ & $15.8 \%$ & $13.6 \%$ & $20.0 \%$ & $0.0 \%$ & $60.0 \%$ & $13.6 \%$ & \\
\hline \multirow{2}{*}{\multicolumn{2}{|c|}{ Total }} & Count & 110 & 38 & 22 & 10 & 6 & 5 & 191 & \\
\hline & & percent & $100.0 \%$ & $100.0 \%$ & $100.0 \%$ & $100.0 \%$ & $100.0 \%$ & $100.0 \%$ & $100.0 \%$ & \\
\hline
\end{tabular}

Source: Tarhini and Hafiz, 2021

According to Fisher's Exact Test, Sig. is greater than 0.05, which means that there is no significant relationship between income and price sensitivity toward necessity products. 
H02: there is no statistically significant relationship between income and price sensitivity toward restaurant services.

Table no. 20: Hypothesis 2

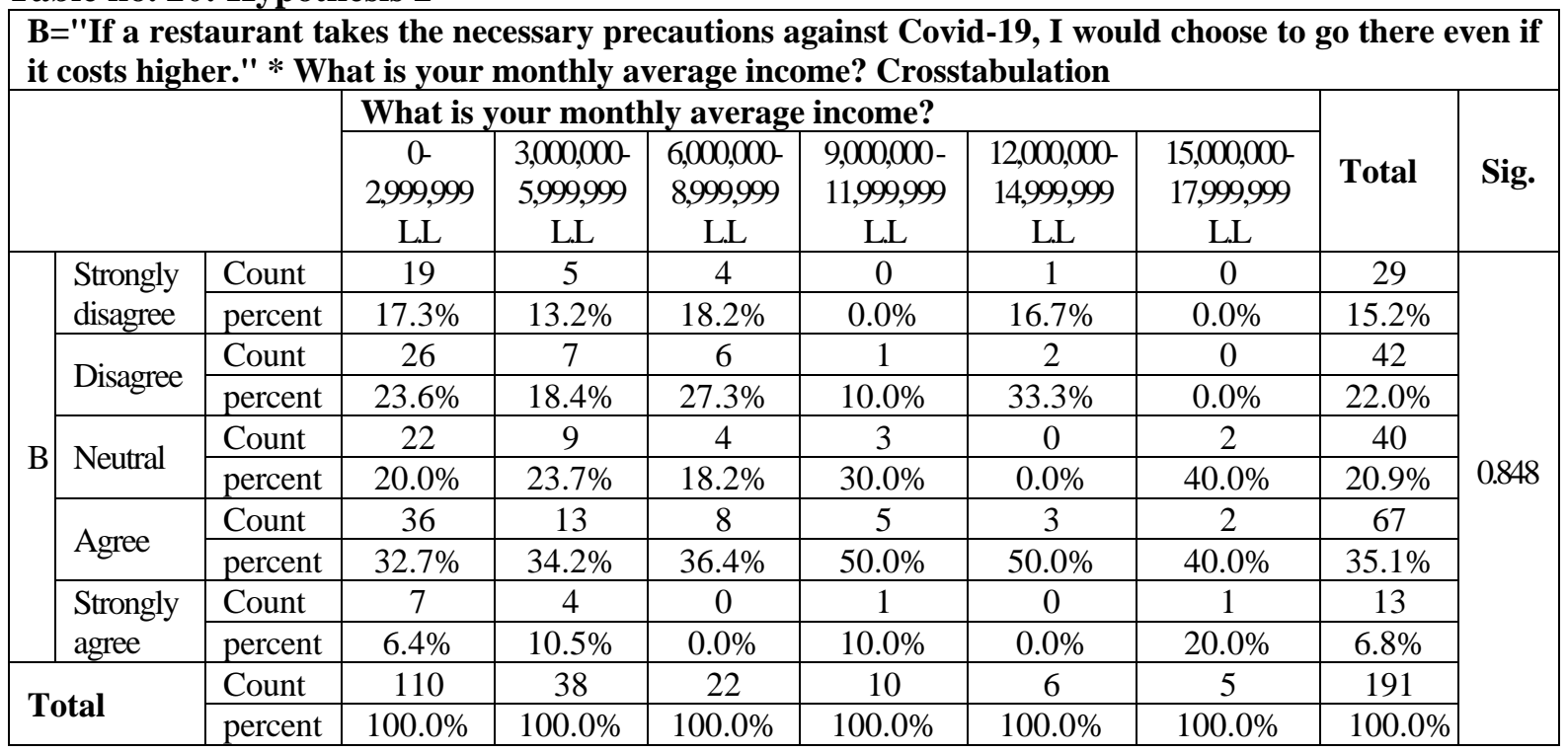

Source: Tarhini and Hafiz, 2021

According to Fisher's Exact Test, Sig. is greater than 0.05, which means that there is no significant relationship between income and price sensitivity toward restaurant services.

H03: There is no statistically significant relationship between the decrease in frequency of visiting physical stores and the frequency of buying through delivery services.

Table no. 21: Hypothesis 3

\begin{tabular}{|c|c|c|c|c|c|c|c|c|}
\hline \multicolumn{9}{|c|}{$\begin{array}{l}\mathrm{C}=\text { "Amid Covid-19, I prefer to buy through delivery services than go in person to buy groceries." } \\
\text { (grocery: food and other commodities) * How has Covid-19 impacted the frequency of your visits to } \\
\text { physical stores? Crosstabulation }\end{array}$} \\
\hline & & & \multicolumn{4}{|c|}{$\begin{array}{l}\text { How has Covid-19 impacted the frequency of your visits to } \\
\text { physical stores? }\end{array}$} & \multirow[b]{2}{*}{ Total } & \multirow[b]{2}{*}{ Sig. } \\
\hline & & & $\begin{array}{l}\text { major } \\
\text { decrease in } \\
\text { frequency }\end{array}$ & $\begin{array}{l}\text { minor } \\
\text { decrease in } \\
\text { frequency }\end{array}$ & $\begin{array}{l}\text { major } \\
\text { increase in } \\
\text { frequency }\end{array}$ & $\begin{array}{l}\text { no real } \\
\text { impact to } \\
\text { frequency }\end{array}$ & & \\
\hline \multirow{8}{*}{$\mathrm{C}$} & \multirow{2}{*}{$\begin{array}{l}\text { Strongly } \\
\text { disagree }\end{array}$} & Count & 19 & 14 & 1 & 9 & 43 & \multirow{10}{*}{0.001} \\
\hline & & percent & $20.7 \%$ & $21.9 \%$ & $10.0 \%$ & $36.0 \%$ & $22.5 \%$ & \\
\hline & \multirow{2}{*}{ Neutral } & Count & 17 & 28 & 2 & 9 & 56 & \\
\hline & & percent & $18.5 \%$ & $43.8 \%$ & $20.0 \%$ & $36.0 \%$ & $29.3 \%$ & \\
\hline & \multirow{2}{*}{ Agree } & Count & 34 & 18 & 4 & 7 & 63 & \\
\hline & & percent & $37.0 \%$ & $28.1 \%$ & $40.0 \%$ & $28.0 \%$ & $33.0 \%$ & \\
\hline & \multirow{2}{*}{$\begin{array}{l}\text { Strongly } \\
\text { agree }\end{array}$} & Count & 22 & 4 & 3 & 0 & 29 & \\
\hline & & percent & $23.9 \%$ & $6.3 \%$ & $30.0 \%$ & $0.0 \%$ & $15.2 \%$ & \\
\hline \multirow{2}{*}{\multicolumn{2}{|c|}{ Total }} & Count & 92 & 64 & 10 & 25 & 191 & \\
\hline & & percent & $100.0 \%$ & $100.0 \%$ & $100.0 \%$ & $100.0 \%$ & $100.0 \%$ & \\
\hline
\end{tabular}

Source: Tarhini and Hafiz, 2021

According to Fisher's Exact Test, Sig. is less than 0.05, which means that there is a significant relationship between the decrease in frequency of visiting physical stores and the frequency of buying through delivery services. The demanding needs for different necessity products make it urgent to buy through channels other than the store itself especially for necessity products.

H04: There is no statistically significant relationship between the decrease in frequency of visiting physical stores and the frequency of buying online. 
Table no. 22: Hypothesis 4

\begin{tabular}{|c|c|c|c|c|c|c|c|c|}
\hline \multicolumn{9}{|c|}{$\begin{array}{l}\mathrm{D}=\text { "Through a safe, convenient and trustworthy source, I would rather buy my groceries online } \\
\text { through an application or a website." * How has Covid-19 impacted the frequency of your visits to } \\
\text { physical stores? Crosstabulation }\end{array}$} \\
\hline & & & \multicolumn{4}{|c|}{$\begin{array}{c}\text { How has Covid-19 impacted the frequency of your } \\
\text { visits to physical stores? }\end{array}$} & \multirow[b]{2}{*}{ Total } & \multirow[b]{2}{*}{ Sig. } \\
\hline & & & $\begin{array}{l}\text { major } \\
\text { decrease in } \\
\text { frequency }\end{array}$ & $\begin{array}{l}\text { minor } \\
\text { decrease in } \\
\text { frequency }\end{array}$ & $\begin{array}{l}\text { major } \\
\text { increase in } \\
\text { frequency }\end{array}$ & $\begin{array}{l}\text { no real } \\
\text { impact to } \\
\text { frequency }\end{array}$ & & \\
\hline \multirow{10}{*}{ D } & \multirow{2}{*}{$\begin{array}{l}\text { Strongly } \\
\text { disagree }\end{array}$} & Count & 4 & 3 & 0 & 5 & 12 & \multirow{12}{*}{0.001} \\
\hline & & percent & $4.3 \%$ & $4.7 \%$ & $0.0 \%$ & $20.0 \%$ & $6.3 \%$ & \\
\hline & \multirow{2}{*}{ Disagree } & Count & 16 & 10 & 1 & 12 & 39 & \\
\hline & & percent & $17.4 \%$ & $15.6 \%$ & $10.0 \%$ & $48.0 \%$ & $20.4 \%$ & \\
\hline & \multirow{2}{*}{ Neutral } & Count & 18 & 24 & 2 & 4 & 48 & \\
\hline & & percent & $19.6 \%$ & $37.5 \%$ & $20.0 \%$ & $16.0 \%$ & $25.1 \%$ & \\
\hline & \multirow{2}{*}{ Agree } & Count & 39 & 23 & 5 & 3 & 70 & \\
\hline & & percent & $42.4 \%$ & $35.9 \%$ & $50.0 \%$ & $12.0 \%$ & $36.6 \%$ & \\
\hline & \multirow{2}{*}{$\begin{array}{l}\text { Strongly } \\
\text { agree }\end{array}$} & Count & 15 & 4 & 2 & 1 & 22 & \\
\hline & & percent & $16.3 \%$ & $6.3 \%$ & $20.0 \%$ & $4.0 \%$ & $11.5 \%$ & \\
\hline \multirow{2}{*}{\multicolumn{2}{|c|}{ Total }} & Count & 92 & 64 & 10 & 25 & 191 & \\
\hline & & percent & $100.0 \%$ & $100.0 \%$ & $100.0 \%$ & $100.0 \%$ & $100.0 \%$ & \\
\hline
\end{tabular}

Source: Tarhini and Hafiz, 2021

According to Fisher's Exact Test, Sig. is less than 0.05, which means that there is a significant relationship between the decrease in frequency of visiting physical stores and the frequency of buying online. Only grocery stores were allowed to open partially during the lockdowns. For any other goods, consumers had the only choice of buying the product only through social media pages or websites and applications. This explains the increase in online shopping even though as shown in the results of the survey, the Lebanese prefer to visit stores in person.

H05: There is no statistically significant relationship between the frequency of visiting physical stores and the spread of Covid-19.

Table no. 23: Hypothesis 5

\begin{tabular}{|c|c|c|c|c|c|c|c|c|}
\hline \multicolumn{9}{|c|}{$\begin{array}{l}\mathrm{E}=\text { Would a Covid-19 vaccine make you visit physical stores more often? } * \text { How has Covid-19 impacted } \\
\text { the frequency of your visits to physical stores? Crosstabulation }\end{array}$} \\
\hline & & & \multicolumn{4}{|c|}{$\begin{array}{l}\text { How has Covid-19 impacted the frequency of your } \\
\text { visits to physical stores? }\end{array}$} & \multirow[b]{2}{*}{ Total } & \multirow[b]{2}{*}{ Sig. } \\
\hline & & & $\begin{array}{c}\text { major } \\
\text { decrease in } \\
\text { frequency }\end{array}$ & $\begin{array}{c}\text { minor } \\
\text { decrease in } \\
\text { frequency }\end{array}$ & $\begin{array}{c}\text { major } \\
\text { increase in } \\
\text { frequency }\end{array}$ & $\begin{array}{c}\text { no real } \\
\text { impact to } \\
\text { frequency }\end{array}$ & & \\
\hline \multirow{6}{*}{ E } & \multirow{2}{*}{ Yes } & Count & 51 & 36 & 4 & 14 & 105 & \multirow{8}{*}{0.290} \\
\hline & & percent & $55.4 \%$ & $56.3 \%$ & $40.0 \%$ & $56.0 \%$ & $55.0 \%$ & \\
\hline & \multirow[b]{2}{*}{ No } & Count & 25 & 18 & 5 & 3 & 51 & \\
\hline & & percent & $27.2 \%$ & $28.1 \%$ & $50.0 \%$ & $12.0 \%$ & $26.7 \%$ & \\
\hline & \multirow{2}{*}{$\begin{array}{l}\text { I don't } \\
\text { know }\end{array}$} & Count & 16 & 10 & 1 & 8 & 35 & \\
\hline & & percent & $17.4 \%$ & $15.6 \%$ & $10.0 \%$ & $32.0 \%$ & $18.3 \%$ & \\
\hline \multirow{2}{*}{\multicolumn{2}{|c|}{ Total }} & Count & 92 & 64 & 10 & 25 & 191 & \\
\hline & & percent & $100.0 \%$ & $100.0 \%$ & $100.0 \%$ & $100.0 \%$ & $100.0 \%$ & \\
\hline
\end{tabular}

Source: Tarhini and Hafiz, 2021

According to Fisher's Exact Test, Sig. is greater than 0.05, which means that there is no significant relationship between the frequency of visiting physical stores and the spread of Covid- 19 .

H06: There is no statistically significant relationship between age and the concern toward Covid-19. 
Table no. 24: Hypothesis 6

\begin{tabular}{|c|c|c|c|c|c|c|c|c|c|}
\hline \multicolumn{10}{|c|}{$\mathrm{F}=$ Choose the most suitable option for you. $*$ What is your age? Crosstabulation } \\
\hline & & & \multicolumn{5}{|c|}{ What is your age? } & \multirow[b]{2}{*}{ Total } & \multirow[b]{2}{*}{ Sig. } \\
\hline & & & $18-24$ & $25-34$ & $35-44$ & $45-55$ & $\begin{array}{l}55 \text { and } \\
\text { above }\end{array}$ & & \\
\hline & \multirow{2}{*}{\begin{tabular}{|l} 
Go out to any \\
restaurant \\
regardless of \\
Covid-19
\end{tabular}} & Count & 10 & 2 & 1 & 0 & 0 & 13 & \multirow{10}{*}{0.114} \\
\hline & & percent & $9.3 \%$ & $4.5 \%$ & $6.3 \%$ & $0.0 \%$ & $0.0 \%$ & $6.8 \%$ & \\
\hline & \multirow{2}{*}{$\begin{array}{l}\text { Go out to a } \\
\text { restaurant that takes } \\
\text { the necessary } \\
\text { precautions against } \\
\text { Covid-19 }\end{array}$} & Count & 26 & 13 & 0 & 0 & 2 & 41 & \\
\hline $\mathrm{F}$ & & percent & $24.1 \%$ & $29.5 \%$ & $0.0 \%$ & $0.0 \%$ & $15.4 \%$ & $21.5 \%$ & \\
\hline & \multirow{2}{*}{$\begin{array}{l}\text { Go out to a } \\
\text { restaurant that takes } \\
\text { the necessary } \\
\text { precautions against } \\
\text { Covid-19 }\end{array}$} & Count & 60 & 20 & 11 & 7 & 9 & 107 & \\
\hline & & percent & $55.6 \%$ & $45.5 \%$ & $68.8 \%$ & $70.0 \%$ & $69.2 \%$ & $56.0 \%$ & \\
\hline & \multirow{2}{*}{ other } & Count & 12 & 9 & 4 & 3 & 2 & 30 & \\
\hline & & percent & $11.1 \%$ & $20.5 \%$ & $25.0 \%$ & $30.0 \%$ & $15.4 \%$ & $15.7 \%$ & \\
\hline \multirow{2}{*}{\multicolumn{2}{|c|}{ Total }} & Count & 108 & 44 & 16 & 10 & 13 & 191 & \\
\hline & & percent & $100.0 \%$ & $100.0 \%$ & $100.0 \%$ & $100.0 \%$ & $100.0 \%$ & $100.0 \%$ & \\
\hline
\end{tabular}

Source: Tarhini and Hafiz, 2021

According to Fisher's Exact Test, Sig. is greater than 0.05, which means that there is no significant relationship between age and the concern toward Covid-19.

H07: There is no statistically significant relationship between income and brand loyalty amid Covid-19.

Table no. 25: Hypothesis 7

\begin{tabular}{|c|c|c|c|c|c|c|c|c|c|c|}
\hline \multicolumn{10}{|c|}{$\begin{array}{l}\text { G=Which of the following statements is most accurate? * What is your monthly average income? } \\
\text { Crosstab }\end{array}$} & \multirow[b]{3}{*}{ Sig. } \\
\hline & & & \multicolumn{6}{|c|}{ What is your monthly average income? } & \multirow[b]{2}{*}{ Total } & \\
\hline & & & $\begin{array}{c}0 \\
2,999,999 \\
\text { LL } \\
\end{array}$ & $\begin{array}{c}3,000,000- \\
5,999,999 \\
\text { LL }\end{array}$ & $\begin{array}{c}\text { 6,000,000- } \\
8,999,999 \\
\text { LL }\end{array}$ & $\begin{array}{c}9,000,000- \\
11,999,999 \\
\text { LL }\end{array}$ & $\begin{array}{c}12,000,000- \\
14,999,999 \\
\text { LL } \\
\end{array}$ & $\begin{array}{c}15,000,000- \\
17,999,999 \\
\text { LL }\end{array}$ & & \\
\hline \multirow[t]{8}{*}{$\mathbf{G}$} & \multirow{2}{*}{$\begin{array}{l}\text { I switch brands } \\
\text { less often today } \\
\text { than ever } \\
\text { before }\end{array}$} & Count & 15 & 8 & 3 & 2 & 1 & 0 & 29 & \multirow[t]{10}{*}{0.032} \\
\hline & & percent & $13.6 \%$ & $21.1 \%$ & $13.6 \%$ & $20.0 \%$ & $16.7 \%$ & $0.0 \%$ & $15.2 \%$ & \\
\hline & \multirow{2}{*}{$\begin{array}{l}\text { I switch brands } \\
\text { about the same } \\
\text { amount as } \\
\text { always }\end{array}$} & Count & 20 & 8 & 9 & 4 & 4 & 1 & 46 & \\
\hline & & percent & $18.2 \%$ & $21.1 \%$ & $40.9 \%$ & $40.0 \%$ & $66.7 \%$ & $20.0 \%$ & $24.1 \%$ & \\
\hline & \multirow{2}{*}{$\begin{array}{l}\text { I switch brands } \\
\text { more often } \\
\text { now than ever } \\
\text { before }\end{array}$} & Count & 72 & 22 & 10 & 4 & 0 & 4 & 112 & \\
\hline & & percent & $65.5 \%$ & $57.9 \%$ & $45.5 \%$ & $40.0 \%$ & $0.0 \%$ & $80.0 \%$ & $58.6 \%$ & \\
\hline & \multirow[t]{2}{*}{ other } & Count & 3 & 0 & 0 & 0 & 1 & 0 & 4 & \\
\hline & & percent & $2.7 \%$ & $0.0 \%$ & $0.0 \%$ & $0.0 \%$ & $16.7 \%$ & $0.0 \%$ & $2.1 \%$ & \\
\hline \multirow{2}{*}{\multicolumn{2}{|c|}{ Total }} & Count & 110 & 38 & 22 & 10 & 6 & 5 & 191 & \\
\hline & & percent & $100.0 \%$ & $100.0 \%$ & $100.0 \%$ & $100.0 \%$ & $100.0 \%$ & $100.0 \%$ & $100.0 \%$ & \\
\hline
\end{tabular}

Source: Tarhini and Hafiz, 2021

According to Fisher's Exact Test, Sig. is less than 0.05, which means that there is a significant relationship between income and brand loyalty amid Covid-19, at the level of switching brands. This is explained in the fact that those with high income can still be loyal to their favorite brands even with a change in price. 
H08: There is no statistically significant relationship between age and the willingness of consumers to visit physical stores.

Table no. 26: Hypothesis 8

\begin{tabular}{|c|c|c|c|c|c|c|c|c|c|}
\hline \multicolumn{9}{|c|}{$\begin{array}{l}\mathrm{H}=\text { How has Covid-19 impacted the frequency of your visits to physical stores? } * \text { What is your } \\
\text { age? Crosstabulation }\end{array}$} & \multirow{3}{*}{ Sig. } \\
\hline & & & \multicolumn{5}{|c|}{ What is your age? } & \multirow{2}{*}{ Total } & \\
\hline & & & $18-24$ & $25-34$ & $35-44$ & $45-55$ & 55 and above & & \\
\hline \multirow[t]{8}{*}{$\mathrm{H}$} & \multirow{2}{*}{$\begin{array}{l}\text { major } \\
\text { decrease in } \\
\text { frequency }\end{array}$} & Count & 51 & 22 & 8 & 5 & 6 & 92 & \multirow[t]{10}{*}{0.558} \\
\hline & & percent & $47.2 \%$ & $50.0 \%$ & $50.0 \%$ & $50.0 \%$ & $46.2 \%$ & $48.2 \%$ & \\
\hline & \multirow{2}{*}{$\begin{array}{l}\text { minor } \\
\text { decrease in } \\
\text { frequency }\end{array}$} & Count & 35 & 15 & 7 & 2 & 5 & 64 & \\
\hline & & percent & $32.4 \%$ & $34.1 \%$ & $43.8 \%$ & $20.0 \%$ & $38.5 \%$ & $33.5 \%$ & \\
\hline & \multirow{2}{*}{$\begin{array}{l}\text { major } \\
\text { increase in } \\
\text { frequency }\end{array}$} & Count & 10 & 0 & 0 & 0 & 0 & 10 & \\
\hline & & percent & $9.3 \%$ & $0.0 \%$ & $0.0 \%$ & $0.0 \%$ & $0.0 \%$ & $5.2 \%$ & \\
\hline & \multirow{2}{*}{$\begin{array}{l}\text { no real } \\
\text { impact to } \\
\text { frequency }\end{array}$} & Count & 12 & 7 & 1 & 3 & 2 & 25 & \\
\hline & & percent & $11.1 \%$ & $15.9 \%$ & $6.3 \%$ & $30.0 \%$ & $15.4 \%$ & $13.1 \%$ & \\
\hline \multirow{2}{*}{\multicolumn{2}{|c|}{ Total }} & Count & 108 & 44 & 16 & 10 & 13 & 191 & \\
\hline & & percent & $100.0 \%$ & $100.0 \%$ & $100.0 \%$ & $100.0 \%$ & $100.0 \%$ & $100.0 \%$ & \\
\hline
\end{tabular}

Source: Tarhini and Hafiz, 2021

According to Fisher's Exact Test, Sig. is greater than 0.05, which means that there is a significant relationship between age and the willingness of consumers to visit physical stores.

\section{Summary of Findings and Analysis}

The significance of the study done is clear in the results that have been described and analyzed. The outcome shows a consistency with what is going on in the whole world. However, a difference is noted regarding online shopping in Lebanon. As opposed to results of a study done in India where $92.2 \%$ agreed to buying goods through E-commerce post lockdown (Chaudhary, 2020). Although almost 50\% of consumers said they would buy their groceries through a safe, convenient and trustworthy online source, only $14.1 \%$ agreed that they would resort online shopping after the pandemic ends. The reasons for such contradiction are due to the absence of online sources and the lack of trust with online sources. The Lebanese industry is still very primitive in the area of online shopping. Another significant finding is the health consciousness that has increased for consumers in Lebanon. This could be implied from the fact that $69.7 \%$ are willing to pay more for necessity health products. Their price sensitivity has decreased for such products, which indicates their value to them. The importance of health is also witnessed in the high ranking given to health as $62.3 \%$ of respondents gave it a rank of six and seven. To add, $70 \%$ of respondents agreed that they have a change in their value system with this experience that they have gone through. The surveyed people gave high ranks to family and health with respect to other elements of the value system. There is no doubt that those findings will have great implications in the world of retail.

\section{Conclusions}

The Covid-19 pandemic has caused fear due to its ambiguity. This is why we must be ready to deal with it on the different levels: economic, health but most importantly human level. As businesses, we must be able to satisfy consumers' needs, as well as understand their motives, feelings, and attitude. We need to equip our businesses with the tools that make it easier for consumers to continue their lives smoothly without it being imperative to make big sacrifices for their lives.

The contribution of this research is the study of the trends that have emerged in Lebanon due to Covid19 to see whether they resemble trends in other countries and if it could be beneficial to utilize the strategies that other countries used to deal with the situation. The other contribution is the hypotheses that have been studied scientifically. The main finding is that the decrease in number of visits to physical 
stores has resulted in an increase in online shopping as well as delivery services. This is why retailers in Lebanon should start to give significance to web channels and establish apps, webpages, and make it appealing, convenient and safe for consumers since executed models are still primitive for this area. Many might still prefer not to visit stores frequently even after the pandemic ends, and if you are able to satisfy their needs through e-commerce, then you have got them as long term customers. According to (Babu \& Kumar, 2020), digital commerce has also seen a boost as new consumers migrate online for grocery shopping. A rise that is likely to be sustained post outbreak.

This research was conducted for the purpose of checking whether changing trends in consumer behavior all over the world has been the same here in Lebanon as well. Results have shown that Lebanese customers have changed their behavior amid Covid-19.

The results of the research are compatible with research in other countries, however, in Lebanon, consumers haven't built great trust with e-commerce and delivery services. This could be related to several reasons: the nature of the Lebanese, being outgoing and like to do everything themselves including shopping as they perceive themselves as savvy and clever. Businesses haven't done enough marketing to communicate their availability online and they haven't focused on building relationships with their customers through continuously interacting with them and solving their problems. Another major concern is that there are no regulations in Lebanon to govern online shopping and making it safe. The willingness to go to physical stores has decreased amid corona as percentages show this is shared with other countries, however, according to McKinsey study this might even continue after the pandemic.

Maybe not the fiercest but definitely one of the most aggressive challenges humanity has ever faced is Covid-19. Like with every other predicament, humans will make it to the end line but with more advancement and learning from mistakes. It is in our nature to cope, and so we have. In fact, $83.2 \%$ of respondents agreed that life after Covid-19 will not be the same as life before it. Consumers have already admitted to new habits like no handshakes, social distancing, health minded buying, focusing on necessities and sanitizing. According to the survey conducted, new habits have been acquired that occupy the time at home like playing the guitar, gardening, playing sports and exercising among others. Many added that they have acquired a new habit that is online shopping. All are more health cautious. These results are consistent with a study conducted in Macedonia which concluded that $78 \%$ of respondents are aware of their changing consumer habits amid Covid-19 (Simović and Marjanović, 2020). This change in the human behavior makes it mandatory for businesses to change some of their strategies and ride the wave professionally.

\section{References}

Aithal, R.K., 2012. Marketing channel length in rural India: Influence of the external environment and rural retailer buyer behavior. International Journal of Retail \& Distribution Management.

Aleksic, A., Ruzic, V. and Baracskai, Z. eds., 2021. Economic and Social Development (Book of Proceedings), 65th International Scientific Conference on Economic and Social. Dynamics, 52(1), pp. 174-183.

Babu, G.C. and Kumar, S., 2020. A Study on Consumer Behavior pattern shift in the period of Corona (COVID-19) Pandemic.

Chaudhary, H., 2020. Analyzing the paradigm shift of consumer behavior towards E-Commerce during pandemic lockdown. Available at SSRN 3664668.

Chauhan, V. and Shah, M.H., 2020. An empirical analysis into sentiments, media consumption habits, and consumer behaviour during the Coronavirus (COVID-19) outbreak. Purakala with ISSN, pp. 0971-2143.

Čvirik, M., 2020. Health Conscious Consumer Behaviour: The Impact of a Pandemic on the Case of Slovakia. Central European Business Review, 9(4), pp. 45-58.

D'Andrea, G., Lopez-Aleman, B. and Stengel, A., 2006. Why small retailers endure in Latin America. International Journal of Retail \& Distribution Management.

Denise, L., 2020. The pandemic is rewriting the rules of retail. Harvard Business Review.

Feeny, A., Vongpatanasin, T. and Soonsatham, A., 1996. Retailing in Thailand. International Journal of Retail \& Distribution Management.

Knoll, C., 2020. Panicked shoppers empty shelves as coronavirus anxiety rises. The New York Times.

Kotler, P., Keller, K.L., Manceau, D. and Dubois, B., 2016. Marketing Management, 15e édition. New Jersy: Pearson Education.

Lahiri, S. and Sinha, M., 2021. A study of the socio-economic implications of the COVID-19 pandemic. Australasian Accounting, Business and Finance Journal, 15(1), pp. 51-69. 
Leone, L.A., Fleischhacker, S., Anderson-Steeves, B., Harper, K., Winkler, M., Racine, E., Baquero, B. and Gittelsohn, J., 2020. Healthy food retail during the COVID-19 pandemic: Challenges and future directions. International journal of environmental research and public health, 17(20), p. 7397.

Lusk, J., 2020. Impacts of coronavirus on food markets.

Mohd Dali, N.R.S., Abdul Hamid, H., Wan Nawang, W.R. and Wan Mohamed Nazarie, W.N.F., 2020. Post Pandemic Consumer Behavior: Conceptual Framework. The Journal of Muamalat and Islamic Finance Research.

Myers, H. and Alexander, N., 1997. Food retailing opportunities in Eastern Europe. European Business Review.

Peter, J.P., Olson, J.C. and Grunert, K.G., 1999. Consumer behavior and marketing strategy.

Revathy, C. and Balaji, P., 2020. Determinants of Behavioural Intention on E-Wallet Usage: An Empirical Examination in Amid of Covid-19 Lockdown Period. International Journal of Management (IJM), 11(6), pp. 92-104.

Reynolds, J., Howard, E., Cuthbertson, C. and Hristov, L., 2007. Perspectives on retail format innovation: relating theory and practice. International Journal of Retail \& Distribution Management.

Rai, A., 2020. Analyses of Consumer Behavior on Online Food Ordering-In reference to COVID-19. Int. J. Res. Eng. Sci. Manag, 3(6), pp. 665-673.

Simović, V. and Marjanović, D., 2020. November. Emerging Trends in Business Economics: Towards Competitiveness, Digitalization and Financial Innovation. In Proceedings (pp. 198-198).

Solomon, M., Russell-Bennett, R. and Previte, J., 2012. Consumer behaviour. Pearson Higher Education AU.

Trappey, C.V. and Lai, M.K., 1996. Retailing in Taiwan: Modernization and the emergence of new formats. International Journal of Retail \& Distribution Management.

University of Warwick., n.d. Warwick education studies. [Online] Available at: https://warwick.ac.uk/fac/soc/ ces/research/current/socialtheory/maps/criticalrealism/ [Accessed 24.05. 2021]. 